Provided for non-commercial research and education use. Not for reproduction, distribution or commercial use.

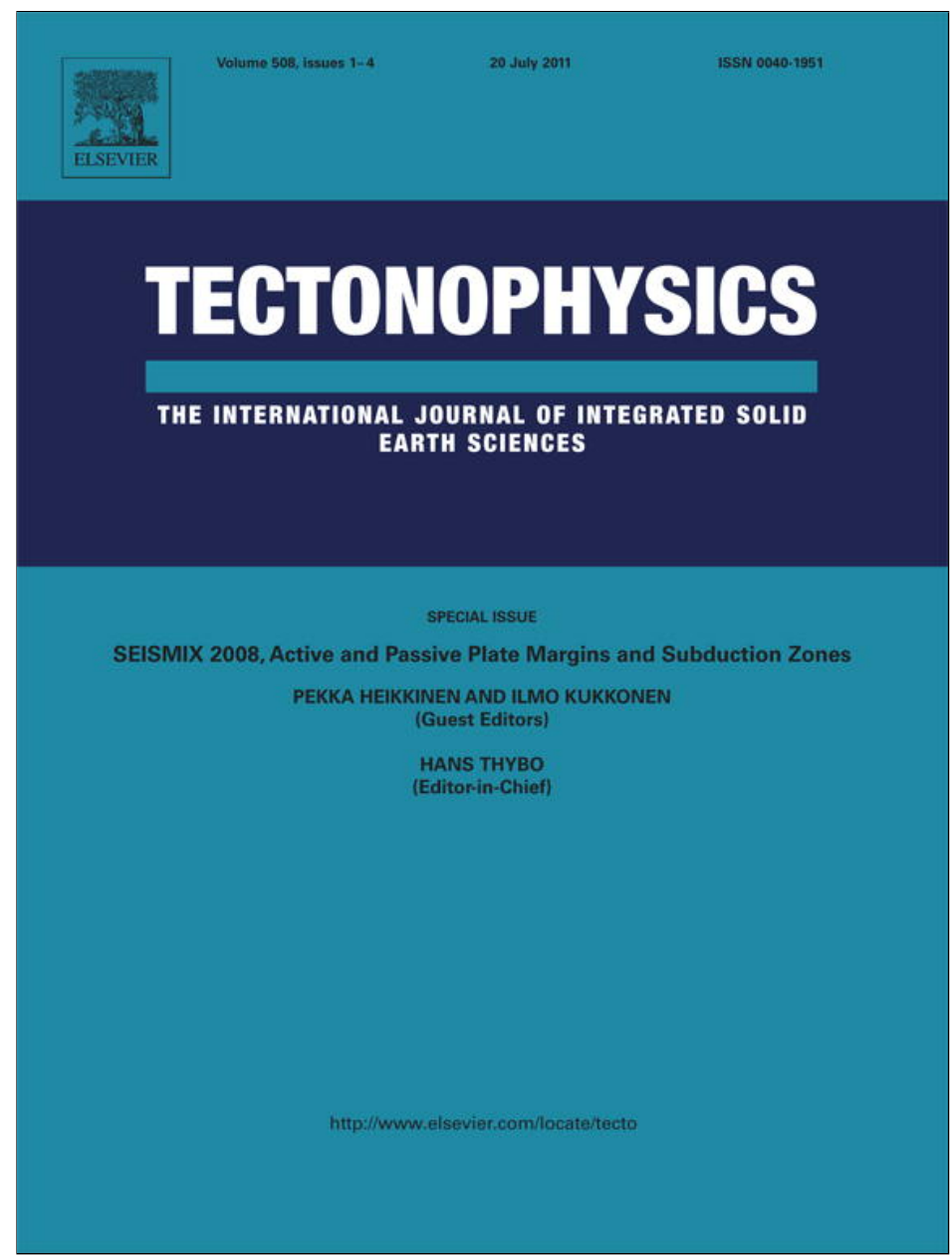

This article appeared in a journal published by Elsevier. The attached copy is furnished to the author for internal non-commercial research and education use, including for instruction at the authors institution and sharing with colleagues.

Other uses, including reproduction and distribution, or selling or licensing copies, or posting to personal, institutional or third party websites are prohibited.

In most cases authors are permitted to post their version of the article (e.g. in Word or Tex form) to their personal website or institutional repository. Authors requiring further information regarding Elsevier's archiving and manuscript policies are encouraged to visit:

http://www.elsevier.com/copyright 


\title{
A crustal seismic profile across Sicily
}

\author{
Flavio Accaino ${ }^{\mathrm{a}, *}$, Raimondo Catalano ${ }^{\mathrm{b}}$, Luigi Di Marzo ${ }^{\mathrm{c}}$, Michela Giustiniani ${ }^{\mathrm{a}}$, Umberta Tinivella ${ }^{\mathrm{a}}$, \\ Rinaldo Nicolich ${ }^{\mathrm{d}}$, Attilio Sulli ${ }^{\mathrm{b}}$, Vera Valenti ${ }^{\mathrm{b}}$, Piero Manetti ${ }^{\mathrm{e}}$ \\ a Istituto Nazionale di Oceanografia e Geofisica Sperimentale, Borgo Grotta Gigante, 42/c, Sgonico, TS, Italy

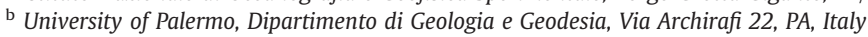 \\ c Geotec SpA, Via G. Barbato, 20, CB, Italy \\ d University of Trieste, Dipartimento di Ingegneria Civile e Ambientale, Via Valerio 10, TS, Italy \\ e C.N.R. Istituto di Geoscienze e Georisorse, Via Moruzzi, 1 PI, Italy
}

\section{A R T I C L E I N F O}

\section{Article history:}

Received 22 January 2009

Received in revised form 1 July 2010

Accepted 14 July 2010

Available online 24 July 2010

\section{Keywords:}

Crustal seismic

Reflection

Refraction tomography

Sicily

Caltanissetta Basin

\begin{abstract}
A B S T R A C T
A crustal reflection seismic profile, more than $100 \mathrm{~km}$ long, was recorded across central Sicily, from the Tyrrhenian shore to the Sicily Channel, to understand the deep structures and the collision mechanisms between Europe and Africa and the subsequent geodynamic evolution. The profile was acquired using explosive sources and 240 active channels recorded by a Sercel 408-XL, 24 bits A/D converter, with a $12 \mathrm{~km}$ spread and a 24 -fold coverage.

The data were processed following a non-conventional procedure in order to preserve the relative amplitudes of the reflections and to better investigate the Sicily deep structures down to the Moho. The main highlighted structures are the dramatic flexure of the Iblean crust, the huge, deeper than expected, trough of Caltanissetta consisting of deep seated thrusts and nappes, and the imbricate thrust system of rigid bodies characterizing the northern Maghrebian chain. We designed an ad hoc acquisition and processing in order to highlight these main geological features in the seismic stacked section. Moreover, the deepest parts of the Caltanissetta trough are imaged for the first time, and its bottom is now fixed at more than $7 \mathrm{~s}$ TWT. The giant crustal wedge flexuring the Iblean foreland and the Moho geometries are examinated.
\end{abstract}

(c) 2010 Elsevier B.V. All rights reserved.

\section{Introduction and geological setting}

During the winter of 2007-2008 a crustal seismic line was acquired in Sicily (Figs. 1 and 2) with the aim of identifying the poorly known deep crustal geometries of the Sicilian-Maghrebian segment of the Apennine system. The acquired line is part of the SIRIPRO (SIsmica a RIflessione PROfonda) multidisciplinary research project for investigating the deep structures of Sicily, a key geodynamical region of the Mediterranean.

The profile acquired in central Sicily (Fig. 2) starts near Termini Imerese on the Tyrrhenian coast, crosses the Sicilian-Maghrebian chain in the north, the Caltanissetta trough in central Sicily, and ends on the southern coast near Gela, close to the outcroppings of the Iblean plateau, foreland of the Sicilian-Maghrebian fold and thrust belt (Fig. 2). The altitude along the profile varies from $930 \mathrm{~m}$ in the northern mountain chain to less than $25 \mathrm{~m}$ at the southern termination.

\footnotetext{
* Corresponding author. Tel.: +39 0402140467.

E-mail address: faccaino@ogs.trieste.it (F. Accaino).
}

The primary objectives of the project are outlined by the following questions:

- Where is the boundary between the African and the Tyrrhenian/ European plates at depth and in which way do both lithospheres interact?

- Is there a pronounced crustal flexure in central Sicily and which are the precise thicknesses of the crust and of the sedimentary layers filling the Caltanissetta trough?

- What is the crustal nature of the foreland and the internal architecture of the chain where a crustal doubling has been proposed?

- Are there shear zones to account for the complex imbrications and wedging and how does the basement interact with the thrust and fold belt?

- How do the shear zones and faults accommodate at depth?

- Are there basic differences in the deep structures between the Maghrebian/Sicilian chain and southern Apennines?

In order to answer these questions, the work is developed in three steps: 1) acquisition and processing of the seismic line to obtain a stacked section; 2) tomographic inversion of the refracted arrivals to get a detailed velocity model of the shallowest part (down to about $2 \mathrm{~km}$ depth); 3 ) analysis of the results. 


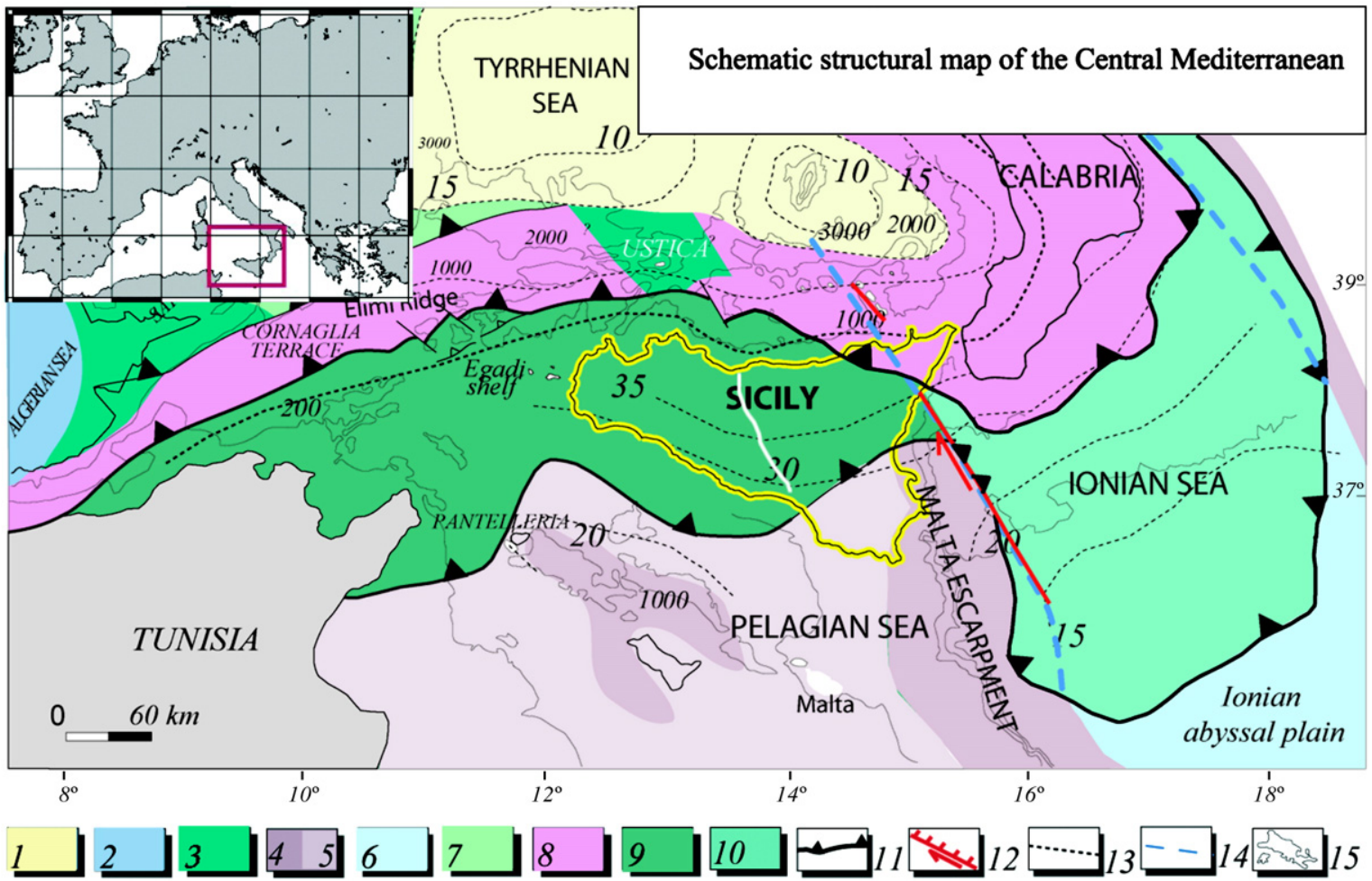

Fig. 1. Map illustrating different crustal sectors of central Mediterranean region (modified from Catalano et al., 1996). 1) Tyrrhenian oceanic crust; 2 ) Algerian Basin oceanic crust; 3 ) thinned Sardinia and Kabilian continental crust; 4, 5) African thinned continental crust; 6) Ionian oceanic crust; 7) Sardinia units; 8) Kabylian-Calabrian units; 9) MaghrebianSicilian units; 10) Ionian accretionary wedge; 11) thrust fronts; 12) fault with strike-slip component; 13) Moho isobaths (km); 14) hypothetic continental-oceanic boundary; 15) bathimetry. Inset shows the location map of the investigated area.

Three seas surround Sicily: to the south, the Pelagian Sea is underlain by the Pelagian Platform with Mesozoic carbonates that include the Pantelleria-Malta grabens as well as the Malta plateau. The Iblean plateau located onshore in the SE of Sicily is the major subaerial exposure of the Pelagian platform. This setting firmly ties the geology of Sicily to that of north Africa, since the Permian (Roure et al., 1990, Casero and Roure, 1994; Catalano et al., 1991).

To the north, the Tyrrhenian Sea crust is composed of Neogene much thinned continental to oceanic crust related to the back arc opening of that domain. Extension in the Tyrrhenian starts in Tortonian, the oceanic spreading in the late Pliocene and Quaternary. Between the southern Tyrrhenian and Sicily outcrops a south-verging segment of the Apennine-Mahgrebrian mountain chain and thrust belt that stretches from the Alps in Europe to the Atlas Mountains in north Africa. This structure records most of the tectonic events involved in the complex interaction of Europe and Africa prior and during the opening and closing of the western Tethys.

To the east, the Malta Escarpment and a belt of prominent active normal faults (Bianca et al., 1999) face this margin of Sicily. These features correspond to the boundary (Casero and Roure, 1994; Nicolich et al., 2000) that limits the continental domain towards the Ionian Sea. In this area, a thinned continental to oceanic crust transition (possibly a remnant of the Tethys) has been proposed by different authors (Catalano et al., 2000a and references therein).

Sicily links the African Maghrebides with the Apennines across the Calabrian accretionary wedge (Fig. 1). The building of the chain is considered the result of both post-collision convergence between Africa and a complex "European" crust (Bonardi et al., 2001) and rollback of the subduction hinge of the Ionian lithosphere.

Three main elements characterize the "collisional" complex of Sicily and adjacent offshore areas (Fig. 2). First, the foreland which outcrops in the SE-corner (Iblean plateau) is submerged by the Pelagian Sea and the adjacent Ionian Sea. The sedimentary cover in the Sicily Channel and in the Ionian Sea is underlain by thinned continental and oceanic crusts, respectively (De Voogd et al., 1992; Catalano et al., 2001). The present day foreland represents a remnant of a Late Jurassic-Early Cretaceous passive continental margin.

Second, a Late Pliocene-Pleistocene NW-dipping foredeep is located along the northern side of the foreland. It is presently buried by the frontal sector of the chain (Gela thrust system) in southern Sicily and in the Gela Basin (Fig. 2). Finally a complex E and SE vergent fold and thrust belt, locally more than $15 \mathrm{~km}$ thick, outcrops on land and is submerged in the adjacent seas. It is formed by a "European" element (Peloritani Units), a "Tethyan" element (Sicilide Units) and an African element (Maghrebian Sicilian Units) (Catalano and D'Argenio, 1982; Roure et al., 1990; Lentini et al., 1994; Catalano et al., 2000a; Finetti, 2005). The stratigraphy and facies domains of the different rock bodies exposed within the chain are briefly summarized in Fig. 3. Interpretation of the several commercial seismic profiles, supported by joint detailed stratigraphy (Fig. 3) and field mapping, has provided regional cross sections illustrating the deeper structures of both western (Catalano et al., 2000b) and eastern Sicily (Casero and Roure, 1994; Bianchi et al., 1989; Bello et al., 2000). It is broadly accepted that a common architecture exists, characterized by an imbricate thrust system to the north, and a stack of S and S-E verging thrusts and nappes to the south (Gela Thrust). These units were presumed to lie on top of the undeformed crystalline basement.

Catalano et al. (2000b), and Bello et al. (2000) distinguished in the Sicily thrust wedge four main structural levels (excluding the Peloritani unit).

The lowest level results from a Meso-Cenozoic, mostly carbonate platform, S-vergent imbricate fans (Trapanese to Iblean units; Fig. 3) overthrusting the Iblean foreland and the Pelagian offshore; this element appears as the main bulk of the chain. The intermediate level is a wedge of flat-lying Meso-Cenozoic deep-water carbonate thrust sheets (Imerese and Sicanian units) overthrusting the deformed carbonate platform rock units. The overlying level is a wedge of nappes of Sicilide deposits and detached terrigenous Numidian flysch. 


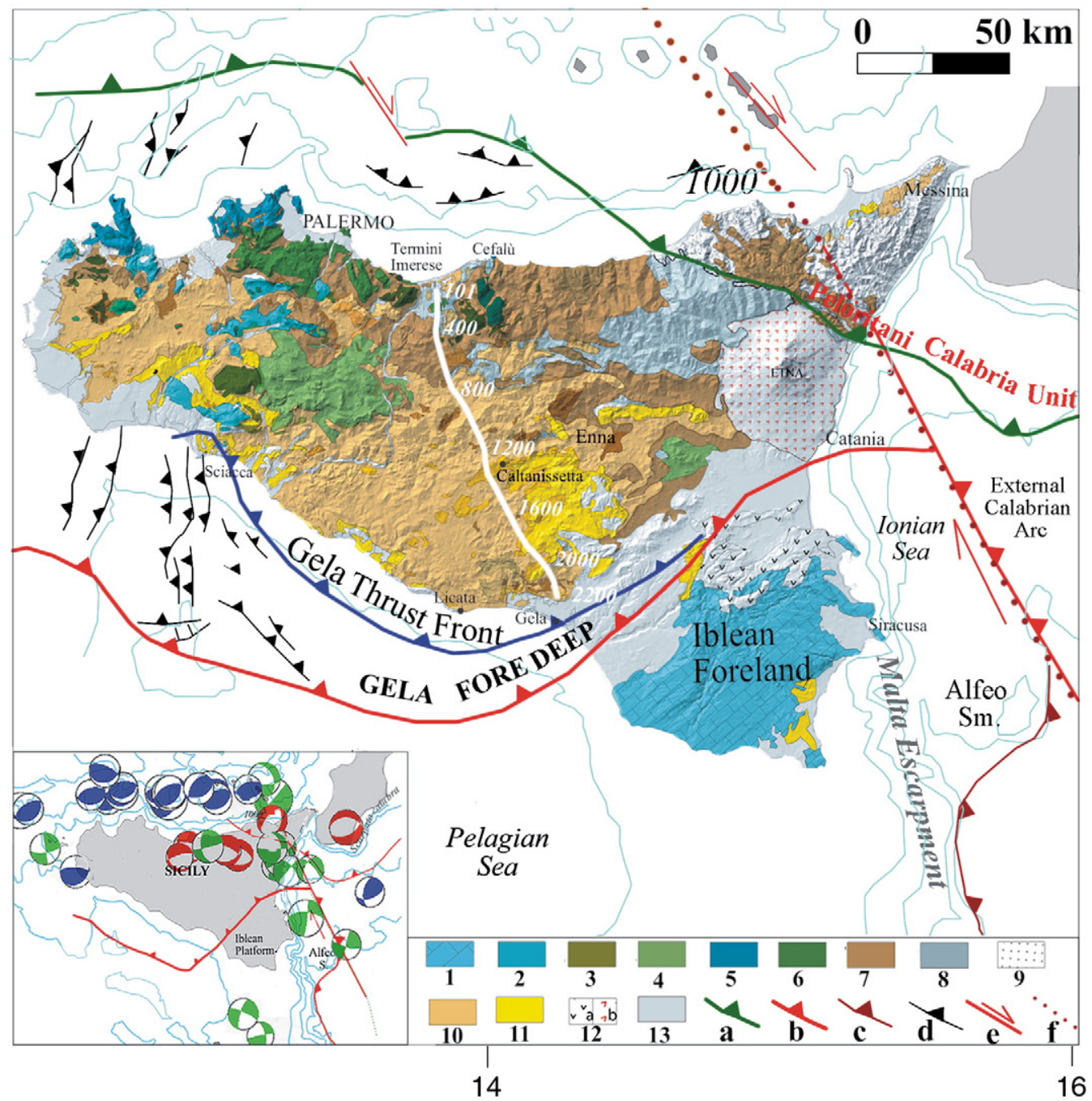

Fig. 2. Structural map of Sicily (modified from Catalano et al., 2000a,b). 1) Iblean units; 2 ) shelf to pelagic carbonate (Trapanese-Saccense) units; 3 ) shelf to deep-water carbonate (Monte Genuardo) units; 4) deep-water carbonate (Sicanian) units; 5) shelf carbonate (Panormide) units; 6) slope to deep-water (Imerese-Panormide) units; 7) Miocene Flyschs; 8) Sicilide units; 9) Calabrian-Peloritani units; 10) Miocene-Pliocene syntectonic deposits; 11) Plio-Pleistocene syntectonic deposits; 12) Plio-Quaternary volcanic rocks; 13) Pleistocene deposits; a) Kabylian-Calabrian thrust front; b) Maghrebian-Sicilian thrust front; c) Ionian accretionary wedge thrust front; d) thrusts; e) faults with strike-slip component; f) hypothetic continental oceanic boundary (modified by Catalano et al., 2000a,b; Chamot-Rooke et al., 2005). In white bold line the location of SIRIPRO profile. In the left-hand corner CMT (1977-2003) focal solutions from the area (after Pondrelli et al., 2004) are also shown. Hypocentral depth: <50 km; Magnitudo>4. Blue: focal mechanisms with compressional regime; green: focal mechanisms with strike-slip regime; red: focal mechanisms with extensional regime.

The upper level consists of syntectonic uppermost Miocene-lower Pleistocene clastics that unconformably seal the whole underlying shortened tectonic units.

The aforementioned tectonic assemblage is the result of two main compressional tectonic phases (Roure et al., 1990; Catalano et al., 2000b). The first one is Middle to Late Miocene in age and caused the overthrusting of the deep-water carbonate rock bodies above the not already deformed platform carbonate substrate. The latter is Pliocene to Lower Pleistocene in age; it deformed with deep seated structures, the platform carbonate units, re-imbricating the previously emplaced deepwater carbonates. In the growing chain, the simultaneous development of thrusts, backthrusts, and lateral displacements (Ghisetti and Vezzani, 1984) and the occurrence of clockwise paleomagnetically detected nappe rotations (Channell et al., 1990; Oldow et al., 1990) during Late Miocene to Middle Pleistocene, produced wedge top basins. These were filled by Miocene-middle Pleistocene syntectonic deposits in the frame of a continuous forward migration (Bianchi et al., 1989; Lentini et al., 1994; Catalano et al., 2000b).

Regional facies analysis indicates (Catalano and D'Argenio, 1982; Catalano et al., 1991; Di Stefano, 1990) that the Paleozoic-Mesozoic to
Paleogene rock assemblages, today found in Sicily, represent the sedimentary cover of distinct paleogeographic domains which belonged to the "Tethyan" ocean and to the African continental margin prior to the onset of the deformation. In contrast, the Miocene-Pleistocene rocks were deposited during and after the deformation of the mentioned domains. The Pelagian foreland and the onland Iblean platform have been extensively investigated by oil exploration. The region underwent the typical evolution of a sunken continental margin in the Mesozoic. Moreover, shape and dimensions of the paleogeographic domains in the region are still preserved (Patacca et al., 1979; Ismail-Zadeh et al., 2003).

The Moho boundary is recognized in seismic data at 9-10 s TWT (Two-Way-Traveltimes) under the Pelagian platform (Catalano et al., 2000b). Previous wide angle reflection/refraction seismic data reveal that the Moho is located at $20 \mathrm{~km}$ on sea and $25 \mathrm{~km}$ along the Sicilian South-Western coasts. Under the fold and thrust belt along the northern edge of the island, the Moho depth is proposed at about $37-38 \mathrm{~km}$ (Cassinis et al., 1969; Colombi et al., 1973). In the Southern Tyrrhenian, the Moho depth ranges from around 25 to only $10 \mathrm{~km}$ in the abyssal plain. The similar setting is observed along the Ionian margin and its abyssal plain with depths ranging from 20 to $16 \mathrm{~km}$, 


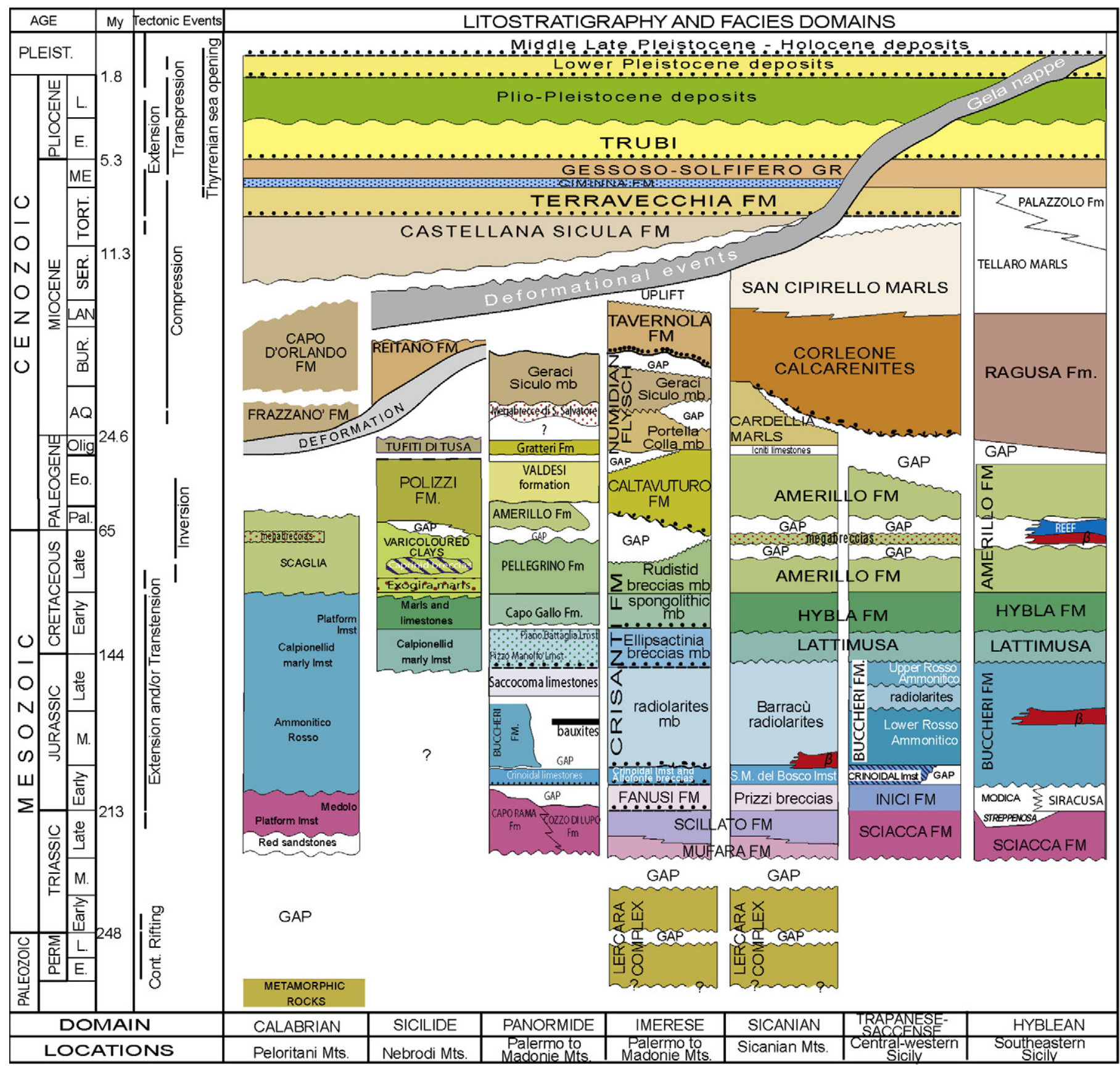

Fig. 3. Stratigraphy and facies domains of the investigated area.

respectively (Giese and Morelli, 1975; Makris et al., 1986; Dal Piaz and Nicolich, 1991; Nicolich et al., 2000; Catalano et al., 2000a).

The top of the magnetic basement shows a strongly variable morphology, with depths from 8 to $10 \mathrm{~km}$ in the S-E, beneath the Iblean domain (Bello et al., 2000), and 10-12 km in the westernmost Sicily sector. The map of the magnetic basement was completed by AGIP and was reported in Morelli (2007). The basement is very deep (more than $14 \mathrm{~km}$ ) in the Caltanissetta trough (Bello et al., 2000) and along the northern coasts of the island (from 10 to $13 \mathrm{~km}$ or more).

Basaltic volcanism occurred since the Jurassic (from the beginning of the opening of the Tethys Ocean) in the western Sicily mountains as well as the Iblean area. Today, the active basaltic volcanism is represented by the active Etna volcano, which started approximately 0.5 Mys ago. The presence of Etna is explained by differential flexure or rollback in the subducting lithosphere beneath the Tyrrhenian Sea (Doglioni et al., 1999; Nicolich et al., 2000).

Major earthquakes occurred in eastern Sicily (Hirn et al., 1997; Bianca et al., 1999; Catalano et al., 2008) along the NNW-trending offshore system of recent faults, in the sector facing the shoreline between Siracusa and Catania, parallel to the Malta Escarpment and to the transtensional fault zone separating Sicily from the Ionian abyssal plain (Casero and Roure, 1994; Cernobori et al., 1996). Recent medium to high magnitude earthquakes were recorded along the $\mathrm{E}-\mathrm{W}$ trending compressive belt (Fig. 2) in the southern sector of the Tyrrhenian Sea (Agate et al., 2000; Montone et al., 2004; Pondrelli et al., 2004). Contractional to transpressional earthquakes were also recorded in southern and western Sicily (Belice valley). Extensional to transtensional mechanisms of seismic events are known from the northern-eastern Sicily belt (MadoniePeloritani) and beneath the Caltanissetta trough (Fig. 2). 


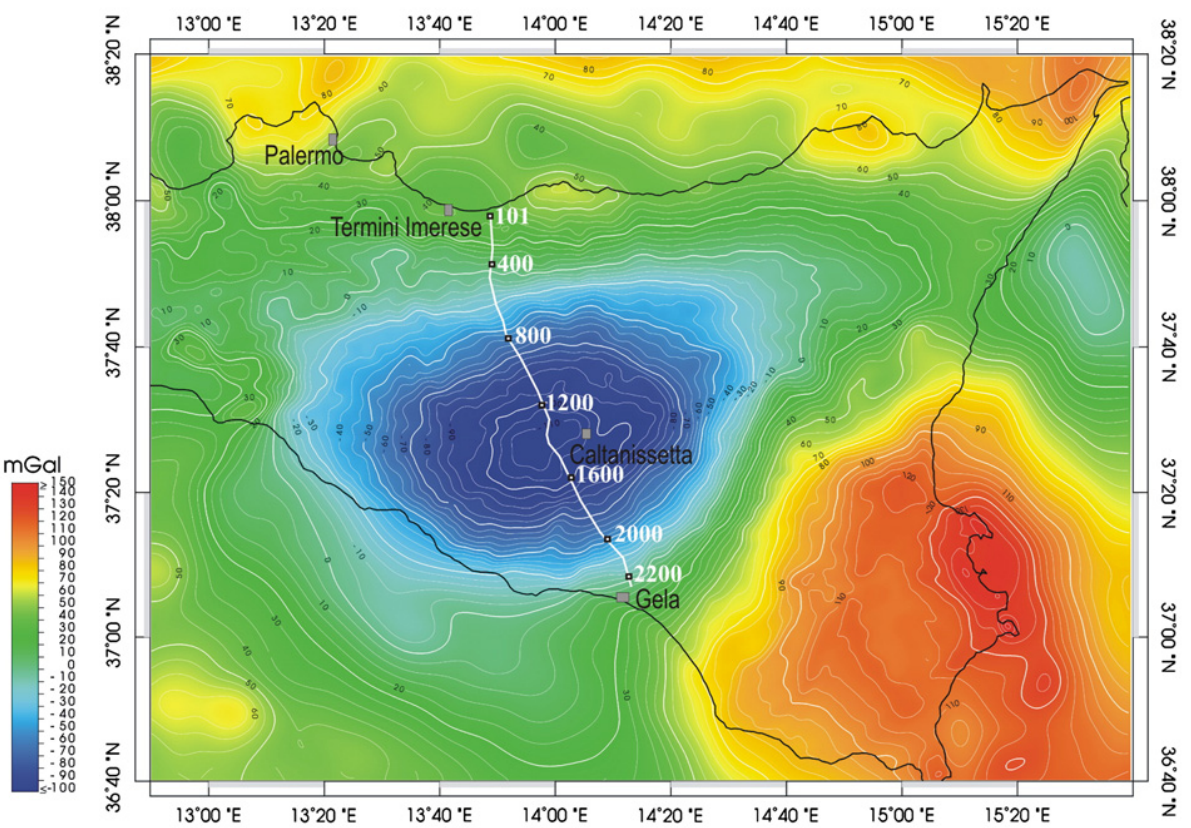

Fig. 4. Location map of the SIRIPRO with station positions. In the background the Bouguer gravimetric map (Ferri et al., 2008) of the area is reported.

\section{Seismic data}

The seismic profile is $106 \mathrm{~km}$ long and crosses a major gravity anomaly shown in Fig. 4 with +200 mGal on the Tyrrhenian side, $+50 \mathrm{mGal}$ in the Pelagian Sea and $-100 \mathrm{mGal}$ in the Caltanissetta trough. A dynamite source was employed with charges ranging from 20 to $30 \mathrm{~kg}$, shot in $24-30 \mathrm{~m}$ deep boreholes. 240 active channels were deployed with receiver spacing equal to $50 \mathrm{~m}$ and with a $12 \mathrm{~km}$ spread connected to a telemetric Sercel 408-XL recording unit with 24 bits A/D converter. The standard shot spacing was $250 \mathrm{~m}$ and the coverage was 24 -fold.

In-line strings of 12 geophones, with a natural frequency of $10 \mathrm{~Hz}$, were deployed with patterns able to reduce high amplitude ground roll. According to structural information and due to the $\mathrm{N}-\mathrm{W}$ dip of the crustal layer, an asymmetrical recording configuration in the southern part of the line was chosen, with a maximum southward offset of $7 \mathrm{~km}$. In the northern part, we switched to a symmetric splitspread geometry with a maximum offset of $6 \mathrm{~km}$. A total number of 402 shots were detonated with 240 active channels for each record. Where the shooting was not permitted for security reasons, we preserved the designed coverage at depth by adding shots with asymmetrical recording geometries. The shot holes were drilled mainly in clays or sandy marls formations.

The profile crosses the Sicilian-Maghrebian chain in a N-S direction, but turns to SSE from Caltanissetta towards Gela, following the Iblean structural trends. Table 1 summarizes the main acquisition parameters.

Table 1

Acquisition parameters.

\begin{tabular}{ll}
\hline Source & Dynamite $(20-30 \mathrm{~kg})$ at depths of 24-30 m \\
\hline Nominal fold & $2400 \%$ \\
Recording instrument & SERCEL 408-XL, 24 bit A/D conversion \\
Number of active channels & 240 \\
Receivers interval & $50 \mathrm{~m}, 12$ geophones, 10 Hz, in-line \\
Recording length & $20 \mathrm{~s}$ with 2 ms sampling rate \\
Configuration length & Symmetric split-spread 6000-150-0-150-6000 m \\
& Asymmetric split-spread 7000-150-0-150-5000 m \\
\hline
\end{tabular}

\subsection{Processing sequence}

The aim of the data processing was the improvement of the signal/ noise ratio to preserve the reflection relative amplitudes, both for the shallowest and deepest structures, in order to maintain their responses and seismic signal characteristics. The following key actions were adopted to obtain the final stacked section presented in Fig. 5. In the first step, the shot/receiver geometry was recreated with the definition of the Common Mid Points (CMP) crooked line. Spherical divergence and surface consistent amplitude correction were applied to compensate for the signal differences caused by geophone ground coupling and diverse energy contributions of each shot.

Vertical resolution was improved by applying a surface consistent deconvolution, choosing parameters on the basis of the autocorrelation function (prediction lag of $28 \mathrm{~ms}$, operator length of $150 \mathrm{~ms}$ and pre-whitening of $1 \%$ ).

The field statics to lead the data to a datum plane (in our case to the sea level) were calculated by tomographic inversion of the first arrivals (explained in the next paragraph), evaluating the near surface velocity variations. After the Normal Move Out (NMO) correction using a preliminary velocity analysis, a trimmed mean-dynamic dip filter and an F-X deconvolution were applied in the shot domain. The trimmed mean-dynamic dip filter computes, at each sample of all the traces, a sequence of trimmed means along rays (dips), using the sample itself and a number of leading and trailing traces (Holcombe and Wojslaw, 1992). With this procedure we removed the ground roll with satisfactory results. Before the F-X deconvolution we added zero traces at the end of each shot, removed after, to avoid influence of a shot to the next one. Fig. 6 shows the same shot before and after the described processing sequence. A new velocity analysis was performed at this point and the definitive NMO correction was applied. The residual statics were computed using a surface consistent approach, referring to a moving window focused on a marker at about 6-7 s TWT. A stretch mute and a CMP stack let us to obtain the output section. Post-stack processing consisted in an F-X deconvolution, in a time-variant filter that decreases linearly from $7-80 \mathrm{~Hz}$ at $0 \mathrm{~s}$ to $7-20 \mathrm{~Hz}$ at $8 \mathrm{~s}$, and in an automatic gain control with a timewindow of $3 \mathrm{~s}$. The processing sequence flow is shown in Table 2. 
(s) $\perp M \perp$

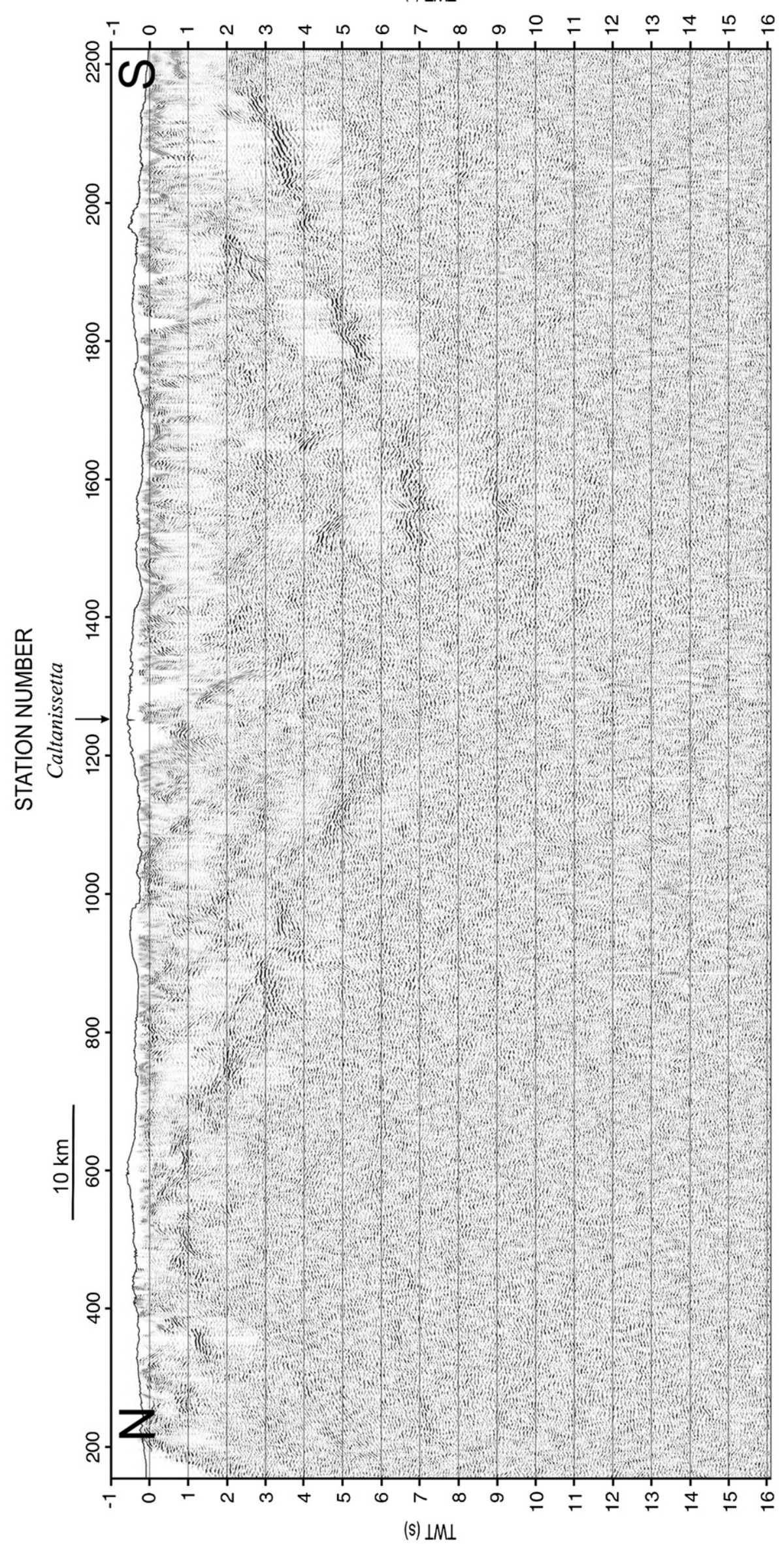



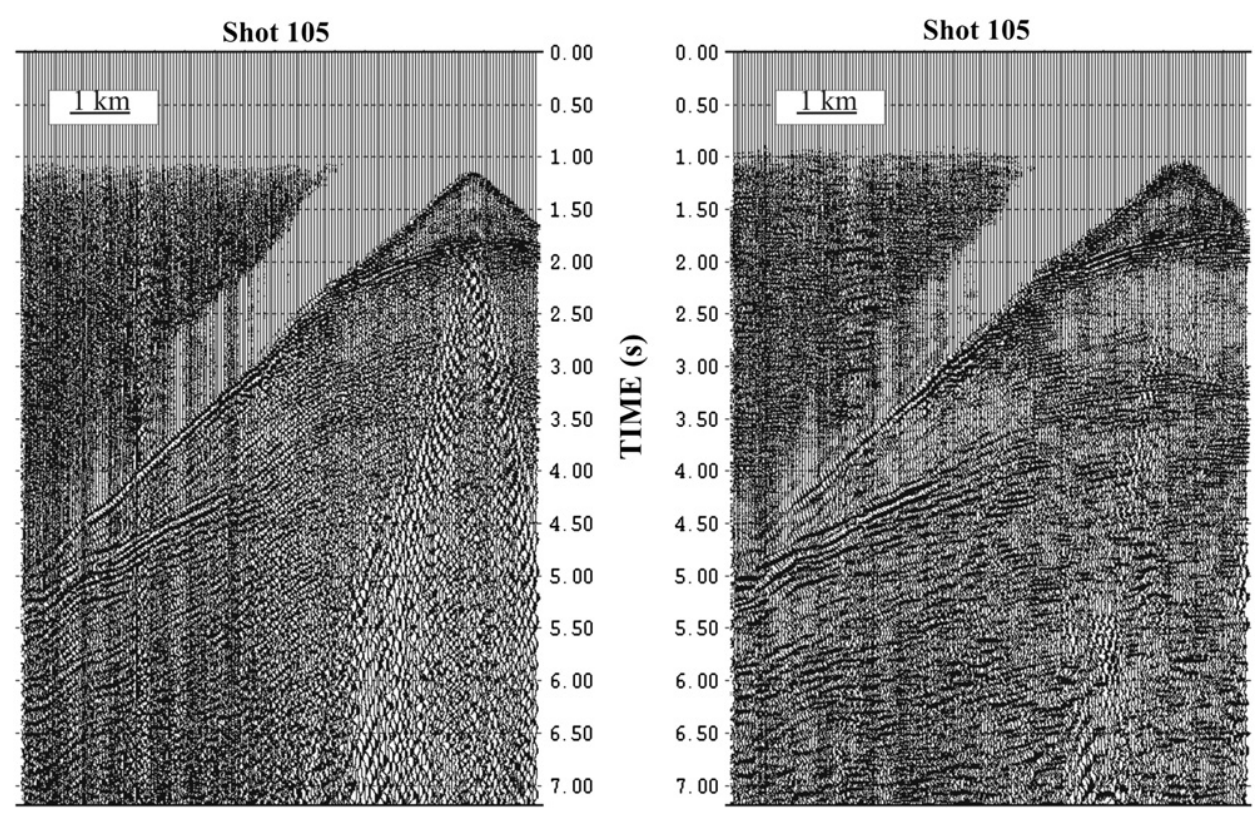

Fig. 6. Comparison of a shot before (left) and after (right) the processing.

\subsection{Tomographic inversion}

The picking of the first arrivals of all the shots was accomplished to obtain information about the shallow velocity structures (up to $1.5 \mathrm{~km}$ below the sea level, i.e. up to $3 \mathrm{~km}$ below the topography), and to compute more reliable statics correcting the seismic traces in the processing sequence. More than 85.000 picks were used simultaneously to perform the inversion. To avoid errors in the picking, an analysis of the apparent velocity of the picks was performed, and the picks with anomalous apparent velocities were neglected (Fig. 7). An initial velocity model was proposed with 30 subparallel interfaces from the maximum field elevation to $7 \mathrm{~km}$ below the sea level. The distance between the interfaces increased linearly with depth from $150 \mathrm{~m}$ to $400 \mathrm{~m}$ down to the above planned $7 \mathrm{~km}$. Horizontally, each layer was subdivided into pixels of $1 \mathrm{~km}$ size. The initial model was designed using a constant velocity of $1500 \mathrm{~m} / \mathrm{s}$.

The tomographic inversion was performed with the software CAT3D, using a modified version of the minimum time ray tracing (Böhm et al., 1999) and an iterative procedure for the inversion, based on the SIRT algorithm (Stewart, 1993). The ray tracing computation starts with an initial path and converges to a final geometry through an iterative procedure by using the analytical solution of Snell's law (Accaino et al., 2007 and references therein).

At the beginning, the first arrivals were inverted using a circumference arc travel path of the rays to obtain an initial model close to the real model. In the subsequent steps, using the results obtained in the previous inversion, the arrivals were inverted assuming the ray path for the diving waves. Afterward, to improve the lateral resolution of the velocity model, the inversion procedure continued utilizing the staggered grid method (Vesnaver and Böhm, 2000) to obtain a final velocity model (Fig. 8) from the near surface.

\section{Discussion}

The velocity field, obtained by the tomographic inversion, is constructed down to about $2000 \mathrm{~m}$ below sea level. This model shows velocities ranging from $1300 \mathrm{~m} / \mathrm{s}$ to $4500 \mathrm{~m} / \mathrm{s}$ (Fig. 8). In the first $30 \mathrm{~km}$ of the northern sector of the profile, the model evidences that the geological formations are characterized by high velocity rock bodies. The latter includes limestones, as calibrated by boreholes.
Velocities greater than $2000 \mathrm{~m} / \mathrm{s}$ are present at very shallow depths increasing to $4500 \mathrm{~m} / \mathrm{s}$ between 0 and $1.5 \mathrm{~km}$ below sea level. Between stations numbers 700 and 1000 , the velocities are lowered and, in addition, lower velocities of $2000 \mathrm{~m} / \mathrm{s}$ are observed in the central and southern sectors, where low velocities reach depths of about $1-1.5 \mathrm{~km}$ below sea level. In this area low velocities are probably associated to low density rocks, which partially explains the occurrence in the Caltanissetta depression of a large negative Bouguer anomaly (Fig. 4). In the central sector of the profile (between stations numbers 1000 and 1150) a high velocity zone (about $3500 \mathrm{~m} / \mathrm{s}$ ) is evident at a depth ranging from 0 to $1 \mathrm{~km}$ below sea level (Fig. 8).

The processed stacked section (Fig. 5) images wedge shaped thrust systems of shallow and deep structures of the crust. In the northern part of the seismic profile (see Fig. 9), the reflectors merge towards south, imaging the stack of imbricate thrusts characterizing the chain. Based on seismic facies characters and borehole calibration, the reflecting body consists (from the top) of Numidian flysch and Sicilidi thrust sheets and of Meso-Cenozoic deep-water carbonates (Imerese and Sicanian thrust units) that overlie thick shallow water carbonate embricates. The wedge is identifiable down to $7 \mathrm{~s}$ TWT, where a decoupling level at the basement-cover boundary may occur. The depth of this interface can be estimated between 14 and $16 \mathrm{~km}$ below the surface, which is in agreement with the depth of the supposed location of the magnetic basement in Tyrrhenian coastal areas of Sicily (Bello et al., 2000). More discontinuous reflections, apparently related to a stack of units of the intermediate and lower crust, are well identified in the deeper crust down to a marker at about $14 \mathrm{~s}$ TWT. This marker is probably related to the African Moho, which was estimated by DSS data at depths of 37-38 km (Cassinis et al., 1969; Colombi et al., 1973; Giese and Morelli, 1975). Offshore, off the northern coast of Sicily (Cefalù Basin), the Moho of the southern Tyrrhenian domain is positioned at depths of $25-26 \mathrm{~km}$ (Giese and Morelli, 1975; Scarascia et al., 1994; Chironi et al., 2000).

In the central part, the thick stack of allochthonous folded and thrusted rigid bodies showing southward vergence forms a wedge in the Caltanissetta trough. Its base can be recognized by the highly reflective top of the Iblean units, down-warped from the southern outcrops to about $7 \mathrm{~s}$ TWT. The depression, shown in Fig. 10, displays, starting from the bottom, shallow and deep-water carbonate thrust units, thick Numidian flysch tectonic slices and Sicilidi nappes, and 
Table 2

Flowchart of the processing adopted to produce the stacked section.

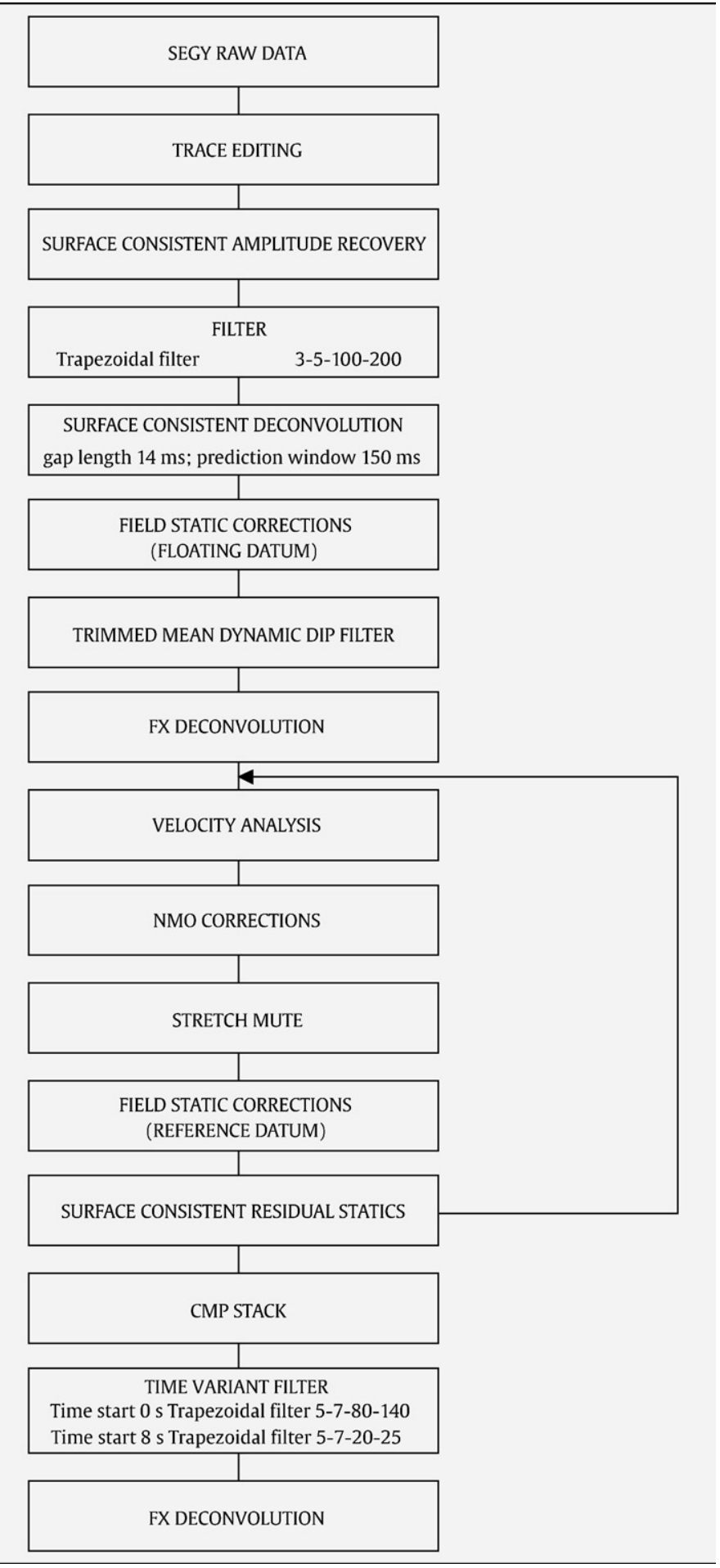

syntectonic Upper Tortonian-Lower Pleistocene terrigenous evaporitic and clastic deposits. The post-Tortonian development of thrusts and backthrusts with related foreland and hinterland verging folds (Catalano et al., 2000b; Bello et al., 2000) is evident in the seismic images immediately north of Caltanissetta (Fig. 5).

Other bright reflections occur inside the terrains located in the depression and emphasize the complexity of the structural setting. The deep seated deep-water carbonate south-verging thrust sheets are partly overlaid by the Gela nappe. The latter appears as a tectonic

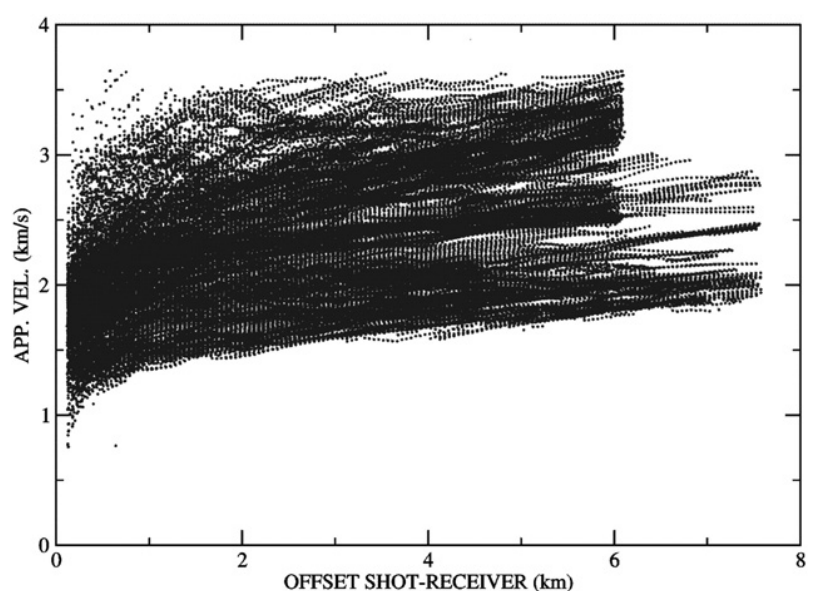

Fig. 7. Apparent velocity versus offset of all picking.

wedge with a common basal decollement underlying to the north the more internal rock bodies.

The buried Iblean foreland units forming a steep regional monocline are deformed by buried NW-dipping normal faults system to some extent reactivated by successive compressional tectonics (Bello et al., 2000). At the southern end of the profile, its basement is at around $5.5 \mathrm{~s}$ TWT and the Moho at about 9-10 s TWT, corresponding approximately to $25 \mathrm{~km}$ depth $(15-16 \mathrm{~km}$ of not sedimentary crust) (Chironi et al., 2000; Catalano et al., 2000a). The Iblean crust thins towards the Caltanissetta depression, where the Moho quickly reaches $12 \mathrm{~s}$ TWT ( $5 \mathrm{~s}$ below the top of the deepest image of the Iblean carbonate platform) at the depression centre. Then, it deeps gently northwards, attaining about 14 s TWT beneath the Tyrrhenian coastline. A complex interaction between the northern thickened crystalline crust and southern Sicilian crust occurs in correspondence of the depression with a strong flexure and a pronounced thinning of the foreland crust.

\section{Conclusions}

The results obtained by the SIRIPRO seismic transect across Sicily evidence that the parameters and procedures adopted in acquisition and processing steps are valuable to identify the crustal deep structures in the study area. Refraction tomography allowed obtaining information about the velocities of shallow structures until $2 \mathrm{~km}$ below the sea level, while the seismic reflection data furnished the images of the geometries of the structures in depth. In particular: (1) in the northern part, a reflector at $7 \mathrm{~s}$ TWT associated to the crystalline

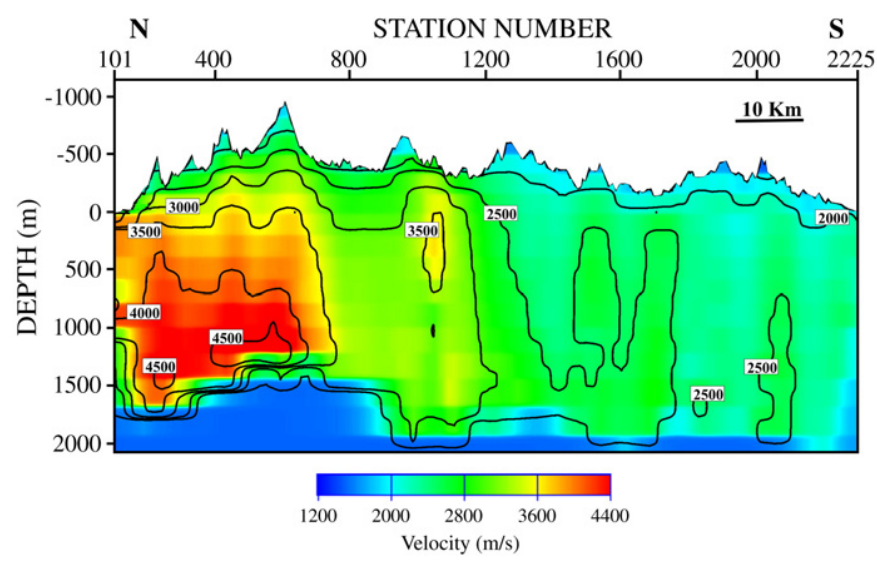

Fig. 8. Shallow velocity field obtained by tomographic inversion of refracted events. 


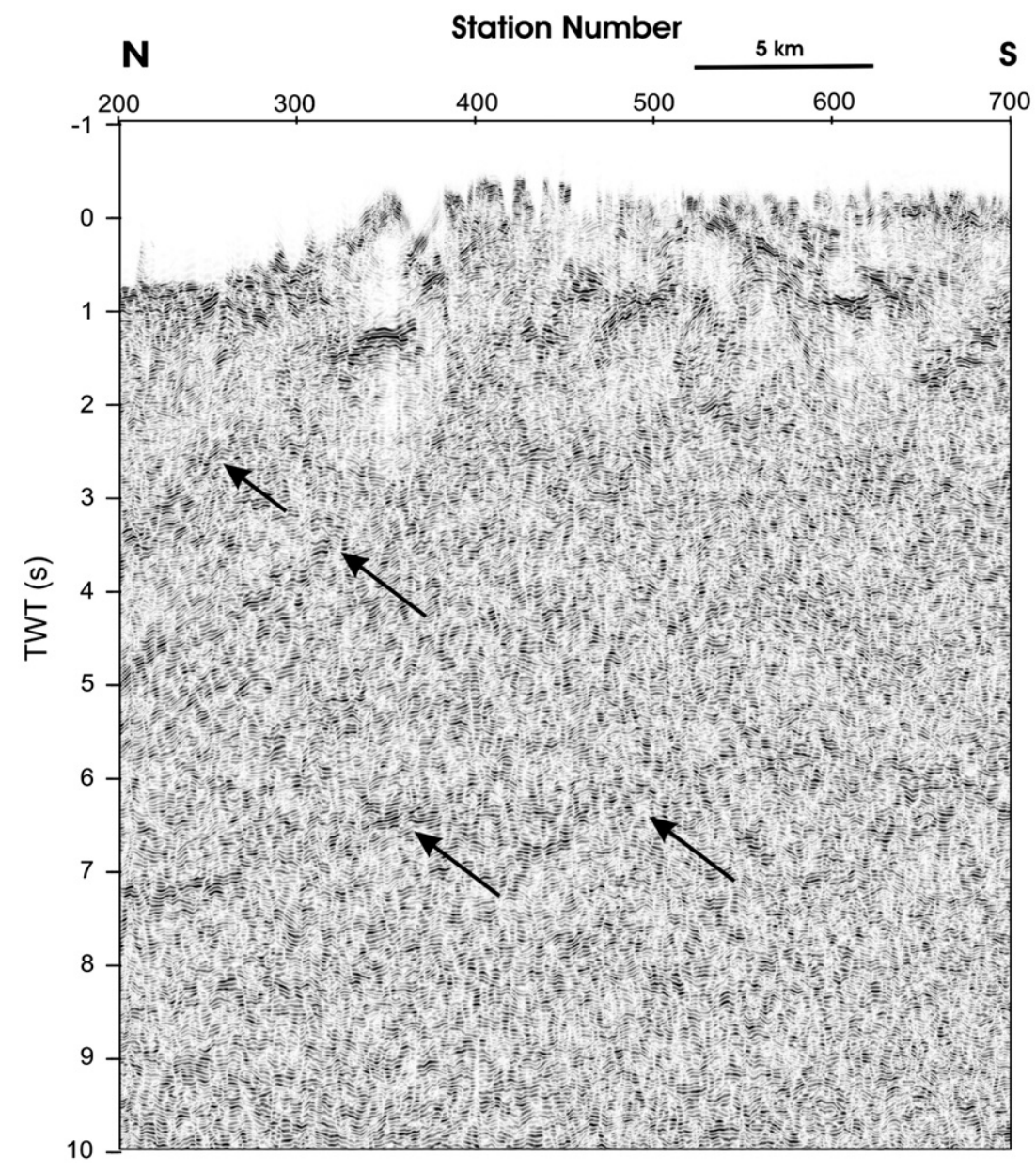

Fig. 9. Detail of the stacked section for the northern sector of the SIRIPRO profile.

magnetic basement is imaged; (2) the deepest part of the Caltanissetta trough is imaged for the first time at about $7 \mathrm{~s} \mathrm{TWT}$; (3) the reflector delimiting the top of Iblean unit is well imaged; (4) the Moho discontinuity can be identified in the northern sector around $14 \mathrm{~s}$ TWT, while beneath the Caltanissetta depression and the Iblean southern sector it can be identifiable at $12 \mathrm{~s}$ TWT and $9 \mathrm{~s}$ TWT, respectively. The crustal thickness appears reduced to approximately $10 \mathrm{~km}$ beneath the Caltanissetta depression and thickened in the northern part of Sicily; (5) the strong flexure of the Iblean foreland suggests a complex interaction between the northern and southern Sicily crusts, which appear to be relatively thin.

\section{Acknowledgments}

SIRIPRO (Sismica a Riflessione Profonda, Deep reflection seismic exploration) is a collaborative Italian Project (scientific leader Prof. R. Catalano) cofinanced by MIUR Italian Research Minister. The authors are very grateful to the two reviewers for their constructive comments which improved the paper. Deep reflection seismic, refraction seismic gravimetry and magnetotelluric data have been acquired by the project partners (Dipartimento di Geologia e Geodesia Palermo University, Istituto di Oceanografia e Geofisica Sperimentale Trieste-OGS, Istituto di Geoscienze e Georisorse CNR Pisa, Centro per la Ricerca Elettronica in Sicilia CRES). The main goal of the SIRIPRO is to define an optimal exploration methodology to study deep crustal lithospheric structures and to integrate the obtained different types of data by means of a software platform. We are very grateful to Claudio Zanolla for the compilation of the Bouguer gravity map utilizing data collected within the SIRIPRO project and from other sources.

\section{References}

Accaino, F., Bratus, A., Conti, S., Fontana, D., Tinivella, U., 2007. Fluid seepage in mud volcanoes of the northen Appennines: an integrated geophysical and geological study. J. Appl. Geophy. 63, 90-101.

Agate, M., Beranzoli, L., Braun, T., Catalano, R., Favali, P., Frugoni, F., Pepe, F., Smriglio, G., Sulli, A., 2000. The 1998 NW Sicily offshore earthquakes: constraints for kinematic model of the southern border of the Tyrrhenian Sea. Mem. Soc. Geol. It. 55, 103-114.

Bello, M., Franchino, A., Merlini, S., 2000. Structural model of Eastern Sicily. Mem. Soc. Geol. It. 55, 61-70.

Bianca, M., Monaco, C., Tortorici, L., Cernobori, L., 1999. Quaternary normal faulting in southeastern Sicily (Italy): a seismic source for the 1693 large earthquake. Geophys. J. Int. 199, 370-394.

Bianchi, F., Carbone, S., Grasso, M., Invernizzi, G., Lentini, F., Longaretti, G. Merlini, S. Moscardini, F., 1989. Sicilia orientale: profilo geologico Nebrodi-Iblei. Mem. Soc. Geol. It. 38, 429-458

Böhm, G., Rossi, G., Vesnaver, A., 1999. Minimum time ray-tracing for 3-D irregular grids. J. of Seism. Expl. 8, 117-131.

Bonardi, G., Cavazza, W., Perrone, V., Rossi, S., 2001. Calabria-Peloritani terrane and northern Ionian Sea. In: Vai, G.B., Martini, I.P. (Eds.), Anatomy of a Mountain: the Apennines and Adjacent Mediterranean Basins. Kluwer Academic Publisher Dordrecht, The Netherlands, pp. 287-306.

Casero, P., Roure, F., 1994. Neogene deformations at the Sicilian-North African plate boundary. In: Roure, F. (Ed.), Peri-Tethian Platforms. Institut Francaise du Petrole Research Conference, Arles, Proceedings. Editions Technip, Paris, pp. 27-50.

Cassinis, R., Finetti, I., Giese, P., Morelli, C., Steinmetz, L., Vecchia, O., 1969. Deep seismic refraction research on Sicily. Boll. di Geof. Teor. Appl. 11, 140-160.

Catalano, R. D'Argenio, B, 1982. Schema geologico della Sicilia. In: Catalano, R D'Argenio, B. (Eds.), Guida alla geologia della Sicilia occidentale. Soc. Geol. It. Guide Geologiche Regionali, pp. 9-41.

Catalano, R., Di Stefano, P., Kozur, H., 1991. Permian circumpacific deep-water faunas from the Western Tethys (Sicily-Italy) - new evidences for the position of the Permian Tethys. In: Channell, J.E.T., Winterer, E.L., Jansa, L.F. (Eds.), Paleogeography and Paleoceanography of Tethys, Palaeogeography, Palaeoclimatology, Palaeoecology, 87. Elsevier, Amsterdam, pp. 75-108.

Catalano, R., Di Stefano, P., Sulli, A., Vitale, F.P., 1996. Paleogeography and structure of the central Mediterranean: Sicily and its offshore area. Tectonophysiscs 260, 291-323. 


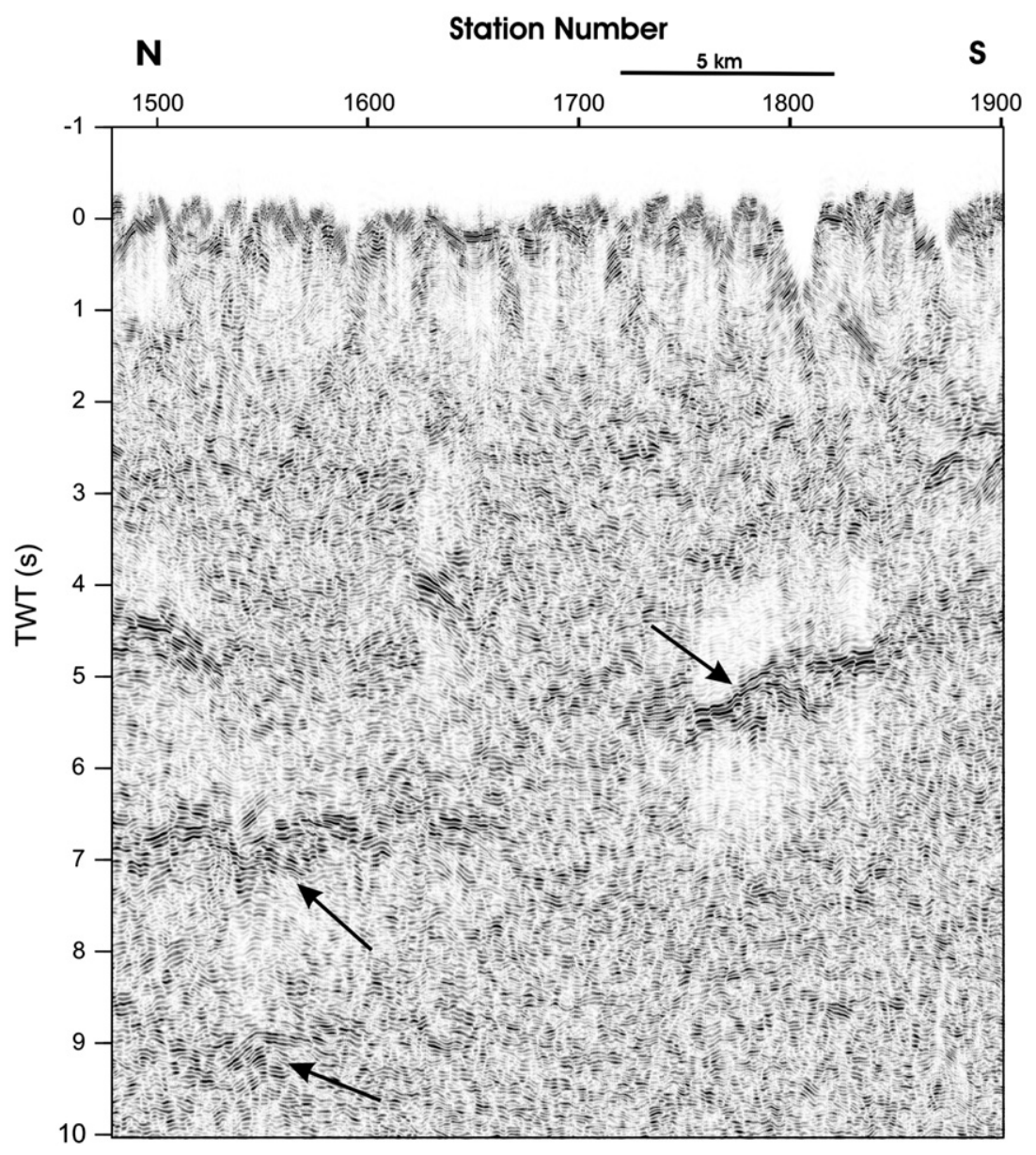

Fig. 10. Detail of the stacked section for the southern sector of the SIRIPRO profile.

Catalano, R., Franchino, A., Merlini, S., Sulli, A., 2000a. A crustal section from North Algerian to the Ionian ocean (Central Mediterranean). Mem. Soc. Geol. It. 55, 71-85. Catalano, R., Franchino, A., Merlini, S., Sulli, A., 2000b. Central Western Sicily structural setting interpreted from seismic reflection profiles. Mem. Soc. Geol. It. 55, 5-16.

Catalano, R., Doglioni, C., Merlini, S., 2001. On the Mesozoic Ionian basin. Geophys. J. Int. $143,1-24$.

Catalano, S., De Guidi, G., Monaco, C., Tortorici, G., Tortorici, L., 2008. Active faulting and seismicity along the Siculo-Calabrian Rift Zone (Soutjern Italy). Tectonophysics 453 , 177-192.

Cernobori, L., Hirn, A., McBride, J.H., Nicolich, R., Petronio, L., Romanelli, M., STREAMER/ Profiles WG, 1996. Crustal image of the Ionian basin and its Calabrian margins. Tectonophysics, 264, pp. 175-189.

Chamot-Rooke, N., Rangin, C., Le Pichon, X., DOTMED working group, 2005. DOTMED: a synthesis of deep marine data in eastern Mediterranean. Mèm. Soc. Gèeol. France $17764 \mathrm{p}$.

Channell, J.E.T., Oldow, J.S., Catalano, R., D'Argenio, B., 1990. Paleomagnetically determined rotations in the western Sicilian fold and thrust belt. Tectonics 9 (4), 641-660.

Chironi, C., De Luca, L., Guerra, I., Luzio, D., Moretti, A., Vitale, M., Group, S.E.A.L.A.N.D., 2000. Crustal structures of the Southern Tyrrhenian Sea and the Sicily Channel on the basis of the M25, M26, M28, M39 WARR profiles. Boll. Soc. Geol. It. 119, 189-203.

Colombi, B., Giese, P., Luongo, G., Morelli, C., Riuscetti, M., Scarascia, S., Schutte, K.G., Strowald, J., De Visentini, G., 1973. Preliminary report on the seimic refraction profile Gargano-Salerno-Palermo-Pantelleria. Boll. di Geof. Teor Appl. 15 (59), 225-254.

Dal Piaz, G.V., Nicolich, R., 1991. Carta della Moho e lineamenti tettonici. C.N.R., P.F. Geodinamica. Structural Model of Italy. sheet 2.

De Voogd, B., Truffert, C., Chamot-Rooke, N., Huchon, P., Lallemant, S., Le Pichon, X., 1992. Two-ship deep seismic soundings in the basins of the Eastern Mediterranean Sea (Pasiphae cruise). Geophys. J. Int. 109, 536-552.

Di Stefano P, 1990. The Triassic of Sicily and the Southern Apennines. Boll. Soc. Geol. It. 109, 21-37.

Doglioni, C., Harabaglia, P., Merlini, S., Mongelli, F., Peccerillo, A., Piromallo, C., 1999. Orogens and slabs vs. their direction of subduction. Earth Sci. Rev. 45, 167-208.

Ferri, F., Zanolla, C., Porfidia, B., Coren, F., Giori, L., Cesi, C., 2008. La cartografia gravimetrica digitale d'Italia alla scala 1:25000. GNGTS, pp. 437-438.

Finetti, I.R., 2005. CROP project: deep seismic exploration of the central Mediterranean and Italy. In: Finetti, I.R. (Ed.), Atlases in Geoscience 1. Elsevier, Amsterdam, pp. 1-794.

Ghisetti, F., Vezzani, L., 1984. Thin-skinned deformations of the Western Sicily thrust belt and relationships with crustal shortening: mesostructural data on the Mt. Kumeta Alcantara. Boll. Soc. Geol. It. 103, 129-157.
Giese, P., Morelli, C., 1975. Crustal structure in Italy. In: Ogniben, L., Parotto, M. Praturlon, A. (Eds.), Structural Model of Italy. CNR-Quaderni de "La Ricerca Scientifica”, Roma, pp. 453-489.

Hirn, A, Nicolich, R, Gallart, J. Laigle, M. Cernobori, L, ETNASEIS,Scientific Group 1997. Roots of Etna volcano in faults of great earthquakes. Earth Planet. Sci. Lett. 148, 171-191.

Holcombe, H.T., Wojslaw, R.S., 1992. Spatially Weighted Trimstackeding: a Technique for Pre-Stacked Noise Suppression. Proceedings Society of Exploration Geophysicists-SEG, Annual Meeting. 1157-1160.

Ismail-Zadeh, A., Cernobori, L., Nicolich, R., 2003. AGU - Computational Seismology and Geodynamics 5, 1-12.

Lentini, F., Carbone, S., Catalano, S., 1994. Main structural domains of the central Mediterranean region and their Neogene tectonic evolution. Boll. Geofis. Teor. ed Appl. 36, 141-144.

Makris, J., Nicolich, R., Weigel, W., 1986. A seismic study in the Western Ionian Sea. Ann. Geophysicae 6B, 665-678.

Montone, P., Amato, A., Pondrelli, S., 2004. Active stress map of Italy. J. Geophys. Res. 104, 25595-25610.

Morelli, C., 2007. Confirmations of and apparent contradictions from the new geophysical deep constraints in the southern Aennines. In: Mazzotti, A., Patacca, E., Scandone, P. (Eds.), CROP-04. Boll.Soc. It, Special Issue, 7, pp. 3-12.

Nicolich, R., Laiglé, M., Hirn, A., Cernobori, L., Gallart, J., 2000. Crustal structures of the Ionian margin of Sicily: Etna volcano in the frame of regional evolution. Tectonophysics 329, 121-139.

Oldow, J.S., Channel, J.E.T., Catalano, R., D'Argenio, B., 1990. Contemporaneous thrusting and large-scale rotations in the western Sicilian fold and thrust belt. Tectonics 9 (4), 661-681.

Patacca, E., Scandone, P., Giunta, G., Liguori, V., 1979. Mesozoic paleotectonic evolution of the Ragusa zone (Southeastern Sicily). Geologia Romana 18, 331-369.

Pondrelli, S., Piromallo, C., Serpelloni, E., 2004. Convergence vs. retreat in Southern Tyrrhenian Sea: insights from kinematics. Geophys. Res. Lett. 31, 1-4.

Roure, F., Howell, D.G., Muller, C., Moretti, I., 1990. Late Cenozoic subduction complex of Sicily. Journ. of Struct. Geology 12 (2), 259-266.

Scarascia, S., Lozej, A., Cassinis, R., 1994. Crustal structures of the Ligurian, Tyrrhenian and Ionian Seas and adjacent onshore areas interpreted from wide-angle seismic profiles. Boll. Geof., Teor. Appl. 36, 5-19.

Stewart, R., 1993. In: Domenico, S.N. (Ed.), Exploration Seismic Tomography: Fundamentals: SEG Course note series, 3, p. 140.

Vesnaver, A., Böhm, G., 2000. Staggered or adapted grids for seismic tomography? Lead. Edge 9, 944-950. 